\title{
The immigrant in me
}

\author{
Zainab Najarali ${ }^{1}$
}

Received: 29 March 2021 / Accepted: 5 June 2021 / Published online: 19 June 2021

(c) Crown 2021

Keywords Immigrant health $\cdot$ Vulnerable populations $\cdot$ Humanities $\cdot$ Emergency medicine

I imagined my parents chose this life and provided to me what was expected not only of them, but of every parent. I felt I earned every achievement awarded to me through my hard work and perseverance. I did not see the long hours my father worked to try and make a life for himself, his three siblings and young family of six. I took the endless support and encouragement I received from my parents for granted, while they kept us blind to their struggle to give us a comfortable life. I pursued higher education and followed my dreams without considering any alternate reality. I am the daughter of immigrant Indian-East African parents, both of whom worked tremendously hard to provide for me the life I take for granted.

These reflections only started to emerge as I navigated medical school and residency. Now, as a third-year Emergency Medicine resident, I think about my parents every single day.

When I interact with patients who are immigrants, I observe the difficulties my parents may have faced. Now, I want nothing more than to make the Emergency Department a safer place for vulnerable populations and to serve as a resource in more capacities than being a medical expert.

I want to positively contribute to reverse the "healthy immigrant effect" and change statistics that reveal a sad truth: immigrants arrive to Canada healthier and their health deteriorates while living here [1].

I recall my 5-year-old patient who immigrated to Canada from Somalia one year ago. She had a rash on her head and her parents had been to dozens of walk-in clinics without avail. Her parents barely spoke English. They stayed up all night trying to comfort her when her scalp would itch relentlessly. They came to the Emergency Department for help. After examining the lesions, we too did not know

Zainab Najarali

Zainab.Najarali@medportal.ca

156 Foley Cres, Maple, ON L6A 4Y8, Canada the diagnosis. I told them to follow up with their Family Doctor and her father looked at me with pleading eyes-a universal look that did not require a translation application to understand. He was desperate to help his daughter. $\mathrm{He}$ did not have access to primary care. He did not know how to use a computer to get onto a waitlist for Family Physicians in the area. I thought I was going to encounter a patient with a simple rash, but this was much more than that. This was health inequity. This was an obvious barrier to healthcare. And this could have been a path to poor health outcomes for my patient and her family going forward.

So we got to work. We enrolled them onto a waitlist for a Family Physician using our computers, organized dermatology follow-up, and created an action plan in the interim to relieve her symptoms.

And then, I prayed a silent prayer that when my parents struggled through the system upon arriving to Canada, someone did them the same honour.

I chose Emergency Medicine to have the privilege of being many patients' first interaction with the healthcare system. Growing up, the Emergency Department was our point of contact for any ailment. We trusted physicians to guide us through the medical system and advocate for us because we did not know how to advocate for ourselves. Today, many of our immigrant patients do not know how to advocate for themselves either, and they desperately need our help.

Immigrant youth are more likely to present to the Emergency Department as a first point of contact for mental health care [2]. I recall my 30-year-old patient who was brought in by his brother for new paranoid delusions. They were both immigrants from Iraq, who moved to Canada 8 years ago in pursuit of a better life. They had no social supports: they only had each other. But in that moment, they also had me. I quickly learned that my patient was presenting with first episode psychosis and that his brother was scared about him, unfamiliar with his symptoms, and worried about losing the only person he had. As I introduced myself and pronounced 
their names correctly, I watched their shoulders relax. I told them I had visited Iraq, and we spoke about their upbringing and immigration to Canada. While my patient described his paranoid delusions, I watched his brother smile. I knew they felt safe, and that I would advocate for them. And I did.

So, what did it take to gain empathy for patients who were immigrants? Better yet, what was the impetus for taking additional steps to improve their experience in the Emergency Department?

I saw my parents in every dreadfully worried father who brought his child to the hospital. I saw my grandmother in every non-native English-speaking elderly patient who struggled to communicate their ailments to doctors.

In my instance, moving toward a more advocacy-based practice required me to gain more empathy. I finally learned how to put myself in my parents' shoes. I saw the world from a different lens, as I observed distressed parents fighting for their children. I thought about how resilient immigrant populations have to be to navigate a healthcare system while speaking a foreign language. My heart ached when I realized that if my patient had not been an immigrant, they may have arrived at a cardiac centre for their acute chest pain instead of the oncology centre down the street. I felt a pit in my stomach when my patient told me they stayed at home with their sick child for one extra day because they last time they came to the hospital they were mistreated for their inability to clearly communicate in English.

For these moments, I vowed to keep fighting for our vulnerable populations; to give them a voice and work to not only improve their experience that day, but to change the trajectory of their health outcomes.

Conflict of interest I do not have any conflicts of interest to declare.

\section{References}

1. Gushulak B. Healthier on arrival? Further insight into the "healthy immigrant effect". CMAJ 2007;176(10).

2. Saunders NR, Gill PJ, Holder L, Vigod S, Kurdyak P, Gandhi S, et al. Use of the emergency department as a first point of contact for mental health care by immigrant youth in Canada: a population-based study. CMAJ 2018;190(40). 